Doświadczenie mistyczne w religiach niechrześcijańskich.

Perspektywa filozoficzna „Filozofia Chrześcijańska” 17 (2020), s. 53-69

ROBERT TROCHONOWICZ

Uniwersytet Marii Curie-Skłodowskiej

\title{
Dōgena Fukan zazengi jako tekst ujawniający istotne rysy buddyjskiej praktyki
}

Sposób praktykowania, zalecanej wszystkim medytacji na siedzaco (jap. Fukan zazengi 普勧坐禅儀) to krótka instrukcja medytacji napisana przez Dōgena (1200-1253) w 1227 roku, zaraz po tym jak powrócił do Japonii ze swojej pielgrzymki z Chin. Jest to pierwsze jego pismo, inaczej niż inne teksty, które nie stało się częścią jego monumentalnego dzieła Oko i skarbiec prawdziwego prawa (jap. Shōbōgenzō 正法眼蔵). W instrukcji tej autor wyjaśnia niezbędne detale dotyczące praktyki medytacji w pozycji siedzącej, związane z postawą ciała, aktywnością umysłu oraz elementami otoczenia. Dōgen napisał dwie wersje tego tekstu Tenpuku Fukan zazengi oraz Koroku Fukan zazengi ${ }^{1}$, dokonując $\mathrm{w}$ tej drugiej kilku pomniejszych zmian i jednej niezwykle istotnej, ponieważ dotyczącej sedna medytacji odbywanej w pozycji siedzącej. Szczegółowe porównanie obydwu tekstów wykracza poza ramy niniejszego artykułu. W związku z tym ograniczę się tylko do stosownych napomnień. W artykule dokonam szczegółowej analizy całego tekstu Koroku Fukan zazengi oraz wzmiankowanej zasadniczej różnicy występującej w przytoczonych wersjach instrukcji.

Każde thumaczenie jest jednocześnie interpretacją i w żadnej innej dziedzinie twórczości literackiej to stwierdzenie nie jest bardziej prawdziwe niż w odniesieniu do pism religijnych. Spośród wszystkich dostępnych tłumaczeń Fukan zazengi zdecydowałem się na wybór przekładu dokonanego przez Carla Bielefelda z roku 1988 z jego książki Dōgen's Manuals of Zen Meditation. Istnieje oczywiście szereg innych tłumaczeń, także nowsze, między

${ }^{1}$ Nazwy er Japonii. 
innymi pochodzące z roku 2003 dokonane przez Nishijimę i Crossa ${ }^{2}$ - którzy również przełożyli Shōbōgenz $\bar{o}^{3}$ na język angielski - jednak po zapoznaniu się z nim odniosłem wrażenie, że bardziej adekwatne jest to dokonane przez Bielefelda. Poza tym jego książka zawiera tłumaczenie obydwu wersji oraz innych instrukcji do medytacji autorstwa Dōgena oraz innych ${ }^{4}$. Pozostałych thumaczeń nie brałem pod uwagę, ponieważ mają one charakter popularny i często zawarta w nich terminologia jest obca pismom Dōgena. W mojej pracy nie korzystam $\mathrm{z}$ oryginału, ponieważ doszedłem do wniosku, że tłumaczenie dokonane przez Bielefeldta jest godne zaufania, biorąc pod uwagę renomę autora, jego drobiazgową znajomość języka oraz literatury zen. Analizę konkretnych cytatów podzieliłem (z grubsza) na akapity, podobnie jak uczynił to Bielefeldt. Jeżeli wydawało mi się to konieczne, dokonywałem analizy każdego poszczególnego zdania. Niekiedy kilka niepozornych napomnień, mówiących o przygotowaniach wstępnych zawiera w sobie ważne wskazówki dla prawidłowego zrozumienia całości. Dlatego właśnie zdecydowałem się na analizę całego - niedługiego wszakże - tekstu, w miarę możliwości nie lekceważąc żadnej z jego części.

\section{Wstępne napomnienia}

Tekst zaczyna się od stwierdzenia zaskakującego paradoksu leżącego u podstaw filozofii Dōgena i obecnego od samego początku w nurcie mahajany. Mowa tutaj o substancjalnej tożsamości ułudy i oświecenia albo, mówiąc inaczej, sansary oraz nirwany. Autor instrukcji zrównuje tę tożsamość z koncepcją jedności praktyki i przebudzenia (jap. shushōichinyo 修証一如), jedną z najważniejszych w pismach Dōgena, a jej sens stanie się jaśniejszy w trakcie analizy tekstu. Oto początek Fukan zazengi:

$\mathrm{Z}$ absolutnego punktu widzenia, z zasady droga [osiągnięcia oświecenia] doskonale przenika wszystko. Jakim sposobem mogłaby pomieścić się jedynie w praktyce i przebudzeniu? Pojazd przodków jest naturalnie nieograniczony; dlaczego więc mamy przejmować się ciągłym wysiłkiem? Z całą pewnością wszystko, co

2 Master Dogen's Shobogenzo: IV Volumes, thum. G. Nishijima, Ch. Cross, Charleston 2006.

${ }^{3}$ Dōgen, Oko i skarbiec prawdziwego prawa, thum. M. Kanert, Kraków, 2005; do samego Shōbōgenzō postaram się nie odnosić zbyt często. Jest to dzieło nazbyt obszerne, wymagające znacznie szerszego omówienia, niż jest to możliwe w formie artykułu.

${ }^{4} \mathrm{~W}$ moim tłumaczeniu z języka angielskiego na język polski starałem się być możliwie jak najwierniejszy oryginałowi, ewentualne uwagi mające rozjaśnić tekst zawarłem w nawiasach kwadratowych. Jeśli chodzi o tłumaczenia nazw japońskich oraz chińskich, najpierw podaję transliterację, a następnie oryginalną pisownię chińską. 
istnieje, jest daleko poza jakimkolwiek splamieniem, kto w takim razie mógłby uwierzyć w istnienie metod oczyszczenia?

Cytat kończy się analogią do słynnego koanu, w którym mnich Mazu rozmawia z mistrzem Nanyue. Rozmowę tę Dōgen dokładnie opisuje w rozdziale dwunastym polskiego wydania Shōbōgenzō ${ }^{6}$ i dotyczy ona zasadniczego paradoksu buddyjskiej praktyki. Aby zrozumieć znaczenie tego fragmentu, potrzebujemy umieścić go w szerszym kontekście biografii autora. Dōgen przez cały okres swojego życia do momentu oświecenia borykał się z wewnętrznym konfliktem. Przyjmował on postać pytania, dotyczącego sensowności praktyki religijnej przy jednoczesnej akceptacji doktryny o wrodzonej oświeconej naturze każdej istoty. To pytanie było głównym impulsem popychającym młodego mnicha $\mathrm{w}$ jego duchowych poszukiwaniach, które ostatecznie zaprowadziły go do Chin, gdzie pod okiem Ruijnga - swojego mistrza - Dōgen uwolnił się od wszystkich wątpliwości. Ironicznie wspomina o tym w dalszym fragmencie: „To [czego szukasz] nigdy nie jest w innym miejscu, jak właśnie w tym [w którym aktualnie się znajdujesz], po co więc pielgrzymować w celu praktykowania tego?"'?.

Według autora Fukan zazengi, mimo że oświecenie jest wrodzone i obecne u każdej żywej istoty, to jednak jego realizacja dokonuje się w konkretnym momencie. To zakłada istnienie procesu linearnego, w którym za pomocą odpowiedniej metody przechodzimy z punktu A do punktu B. Mimo to, w tekście Dōgen przedstawia sprawę $\mathrm{z}$ tych dwóch punktów widzenia. $\mathrm{Z}$ jednej strony proces osiągania oświecenia jest linearny, jednak $z$ drugiej strony zawsze należy zaznaczyć, że wydarza się on w szerszym kontekście, jakim jest proces cyrkularny, w którym początek i koniec stykają się w tym samym punkcie. $Z$ tego punktu widzenia wszelki ruch jest jedynie pozornym procesem samodzielnej realizacji tej zaskakującej prawdy. Należy pamiętać, że ta pozorność jawi się jako taka dla oświeconego umysłu, zaś dla większości pogrążonych w ułudzie ludzi - jest realną przepaścią. Mówi o tym ostatni fragment pierwszego akapitu: „A jednak, jeżeli zaistnieje najmniejsze rozróżnienie, choćby cienkie jak włos, powstanie wtedy luka jak pomiędzy niebem a ziemią. W momencie kiedy pojawi się nawet najdrobniejsze upodobanie lub niechęć, wszystko staje się pomieszane a umysł zagubiony".

Przeciwieństwem umysłu zagubionego jest umysł poszukujący drogi (jap. hotsu bodaishin 発菩提心), który w pismach Dōgena oznacza postawę bezkompromisowej aspiracji do osiągnięcia doskonałego oświecenia

\footnotetext{
C. Bielefeldt, Dōgen's Manuals of Zen Meditation, Berkeley 1988, s. 175.

Dōgen, Oko i skarbiec prawdziwego prawa, s. 215-222.

C. Bielefeldt, Dōgen's Manuals..., s. 175.
} 
dla dobra innych. Stanowi ona synonim występującego w pismach Nagarjuny sanskryckiego terminu bodhicitta (बोधचित्ति), o bliskim mu znaczeniu. Jednak $\mathrm{u}$ Dōgena ten termin nabiera dramatycznego zabarwienia. Oznacza on bowiem gotowość do praktykowania prawa Buddy (sanskryt. dharma, jap. hō ホウ) w nieskończoność - czyli przez niekończące odradzanie się - bez względu na obecność oświecenia lub jego brak. Taka radykalna postawa sama w sobie jest już oświeceniem, a sama praktyka może być rozumiana jako proces godzenia się z tym traumatycznym rdzeniem.

Kolejny fragment jest przestrogą przed straceniem umysłu poszukującego drogi, czyli błędnym przeświadczeniem polegającym na zaprzestaniu praktyki po dostąpieniu połowicznego wglądu, lub wyrażeniem przekonania, że dyskursywna wiedza jest powodem do dumy. Kontynuując myśl, autor pisze tak:

Mimo dumy z własnego zrozumienia, przesycenia wglądem, oraz penetrującą wszystko mądrością. Mimo tego że osiągnąłeś drogę i opanowałeś sposób na oczyszczenie umysłu, oraz uwzniośliłeś się tak, że zawstydzasz niebiańskie istoty, to jednak wciąż możesz włóczyć się po obrzeżach wejścia i wciąż odczuwać brak na niezrównanej ścieżce wyzwolenia ${ }^{8}$.

Każde doświadczenie religijnego wglądu, którego adept jest świadom, $\mathrm{z}$ całą pewnością nie może być uznany za realne oświecenie. Dzieje się tak, ponieważ świadomość oświecenia jest jednocześnie świadomością samego siebie, a to już samo w sobie zawiera nieredukowalny element egotyzmu. Dlatego niezwykle istotnym punktem praktyki jest sukcesywne odrzucenie wszystkich takich doświadczeń jako złudzeń wbijających w arogancję. W związku z tym termin umysł poszukujący drogi możemy oddać jako postawę pokory, zaś jej utratę jako pychę.

W kolejnym fragmencie Dōgen - celem uprawomocnienia swojej wizji praktyki zen - powołuje się na tradycję, czyli autorytet linii przekazu buddów i patriarchów:

Nawet w przypadku mędrca z Jetavany, mimo jego wrodzonej mądrości, wciąż możemy zauważyć ślady jego sześcioletniego wyprostowanego siedzenia, a także innego mędrca z Shao-lin, który mimo tego, że przyjął pieczęć umysłu, to wciąż słyszymy o sławie jego dziewięcioletniego wpatrywania się w ścianę. Skoro nawet starożytni mędrcy byli tacy, to dlaczego współcześni ludzie ociągają się w poszukiwaniach Drogi? ${ }^{9}$

\footnotetext{
${ }^{8}$ Tamże, s. 176.

9 Tamże.
} 
Mowa tutaj o historycznym Siakjamunim oraz Bodhidharmie - legendarnym pierwszym patriarsze chińskiego chanu. To odniesienie do przykładów starożytnych mistrzów jest jednym z najważniejszych motywów w pismach Dōgena i uprawomocnieniem wszystkiego, czego nauczał. Należy zauważyć, że nie jest to tylko sprytne posunięcie doktrynalne, ale faktycznie empiryczna obserwacja. Dawni mistrzowie praktykowali medytację, siedząc, również po osiągnięciu oświecenia, co prowokuje pytanie o prawdziwe znaczenie praktyki w buddyzmie zen. Medytacja jako sposób osiągnięcia oświecenia przez istoty pogrążone w ułudzie to tylko pół prawdy, drugie pół to rozumienie medytacji jako modus vivendi oświeconych istot. Praktyka jest jednocześnie drogą do oświecenia i ekspresją oświeconej natury. To właśnie w tym całościowym sensie, na podstawie przykładów z przeszłości, Dōgen prezentuje medytację widzianą niejako z perspektywy początku oraz perspektywy końca. Paradoksalność takiego myślenia wprawia w zakłopotanie i nie jest to przypadkiem. Będąc nauczycielem, wpisującym się w tradycję buddyzmu chan i zen, autor Fukan zazengi zamieszcza w swych pismach najbogatszy zbiór koanów, czyli niezwykłych sytuacji z życia dawnych mistrzów, które - głównie w szkole rinzai, ale nie tylko - stanowią dla mnichów obiekt nieustającej kontemplacji. W odniesieniu do chińskiej tradycji cáodòng (曹洞宗), którą zainicjował w Japonii Dōgen pod nazwą sōtō, element introspekcji koanu nie jest wyrażony wprost $\mathrm{w}$ tekstach tej tradycji. Jednak należy pamiętać o przykładzie samego autora Shōbōgenzō, którego do oświecenia nie doprowadziła znajomość jakichś ezoterycznych nauk ani sekretnych technik medytacyjnych, a właśnie problematyczne pytanie, które stanowiło palący problem, popychający go do tytanicznego duchowego wysiłku. Odpowiedź na to paradoksalne pytanie (jap. kōan 公案), które stanowi esencję duchowej pielgrzymki, nie może być odnaleziona za pomocą sił intelektu. Dōgen kontynuuje: „Dlatego zaprzestań intelektualnych wysiłków interpretacji słów i pogoni za mowami [dharmy]. Przeniknij [uczyń], krok wstecz zapalający światło oświetlające wszystko" ${ }^{10}$. Jeśli chodzi o uwolnienie się od niepokoju, rozważania intelektualne nie mają dużego znaczenia. Medytacja sama w sobie stanowi zagadkę, której nie można pojąć przy udziale intelektu, wręcz przeciwnie, to jego odrzucenie stanowi ów krok wstecz, a więc zaprzestanie pogoni za zrozumieniem, które za pomocą konceptu nieudolnie stara się petryfikować rzeczywistość. Odrzucanie wszystkich form intelektualnego zafałszowania jest jednym z zasadniczych punktów praktyki. Indyjski mędrzec Jiddu Krishnamurti w swoim przemówieniu w Ojai z 16 czerwca 1934 roku, stwierdza, że konflikt może istnieć wyłącznie pomiędzy fałszem i fałszem, a nigdy pomiędzy prawdą i fałszem, tak jak nigdy nie może istnieć walka pomiędzy światłem

10 Tamże. 
i ciemnością ${ }^{11}$. Podobnej analogii światła i ciemności używa Dōgen w przytoczonym fragmencie Fukan zazengi, w którym zaprzestanie pogoni za konceptualizacją jest tożsame z zapaleniem wewnętrznej lampy, która w jednej chwili oświeca i niszczy ciemność ignorancji.

W kolejnych zdaniach tekstu przyciąga uwagę określenie doświadczenia oświecenia u Dōgena jako puszczenia ciała i umysłu (jap. shinjin datsuraku 身心脫落): „Ciało i umysł odpadną same z siebie, a Twoja Pierwotna Twarz się wyłoni" $"$.

Jest to sformułowanie, które autor przypisuje swojemu mistrzowi Ruijngowi i oznacza pozostawienie za sobą wszystkich trosk związanych z ciałem oraz umysłem - co pokrywa się $\mathrm{z}$ innym często powtarzanym w pismach Dōgena pouczeniem związanym z odrzuceniem zysku i sławy. Termin dotyczy stosownych przygotowań $\mathrm{w}$ związku z podjęciem praktyki, tak aby żadne światowe namiętności nie naprzykrzały się adeptowi. Zysk oraz sławę możemy dopasować odpowiednio do namiętności ciała oraz umysłu, pierwsza bowiem dotyczy przyjemności, a druga arogancji intelektualnej wynikającej ze znajomości doktryny, która budzi zdumienie wśród innych i jest przyczynkiem do przykładania wagi do opinii społecznej. Obie te namiętności powinny zostać odrzucone, a prawdziwie oświecony człowiek to taki, który w szystko porzucił i wszystko zapomniał. Kiedy ani ciało, ani umysł nie stanowią już żadnej przeszkody, wtedy wyłania się coś, co w literaturze chanu i zenu nazywane jest między innymi Pierwotną Twarzą (jap. honrai menmoku 詠本来面目). Trzeba jednak przypomnieć, że proces sytuowania się $\mathrm{w}$ tej rzeczywistości należy rozumieć przede wszystkim cyrkularnie. W związku z tym porzucenie zysku i sławy i rozpoczęcie praktyki zen jest już samo w sobie odrzuceniem ciała i umysłu, co potwierdza ostatnie zdanie przytoczonego fragmentu: „Jeżeli chcesz tego stanu, pośpiesznie praktykuj ten stan” ${ }^{13}$.

Jest to ważne zdanie, które Dōgen przytacza również pod koniec analizowanego tekstu, dlatego pozostawiam go tutaj bez komentarza.

Kolejne fragmenty tekstu opisują techniczny wymiar siedzenia: „Dla studiowania zen, najlepszy jest cichy pokój”"14. Ciche pomieszczenie nie powinno oznaczać eliminacji wszystkich dźwięków, w przeciwnym wypadku autor instrukcji proponowałby również odcięcie zmysłu wzroku, a jak przekonujemy się dalej, wyraźnie zastrzega, że oczy podczas praktyki powinny pozostać otwarte. Ten fragment jest kolejnym punktem, wskazującym na odmienną wizję medytacji od stereotypowego poglądu, mocno osadzonego $\mathrm{w}$ tradycji Jogasutr, w którym to duchowa praktyka (sadhana) przedstawiana jest jako

\footnotetext{
11 J. Krishnamurti, Total Freedom, San Francisco 1996, s. 26.

12 C. Bielefeldt, Dōgen's Manuals..., s. 176.

13 Tamże.

14 Tamże, s. 177.
} 
powolny proces stopniowej deprywacji sensorycznej. U Dōgena taka forma praktyki jest niedopuszczalnym odejściem od poglądu jedności sacrum i profanum ergo nirwany i sansary ergo praktyki i oświecenia. $Z$ jednej strony adept nie powinien okazywać zainteresowania światem, ale jednocześnie winien nie odcinać się od niego. Wiąże się to z kolejnym nakazem dotyczącym zachowania zdrowego rozsądku w spożywaniu posiłków: „Bądź umiarkowany w jedzeniu i piciu" 15 .

Lakoniczne wspomnienie o diecie odkrywa niechęć do ascetyzmu rozumianego jako aktywne umartwianie ciała. W buddyzmie sukces nie jest uzależniony od wytrzymałości na ból. Inaczej przedstawia się sytuacja w kwestii realizacji doczesnych planów oraz relacji międzyludzkich. Tutaj Dōgen zaleca radykalizm: „Odsuń od siebie wszelkie zaangażowanie i zakończ wszystkie relacje" $"$.

Warto wspomnieć, że w toku dziejów, buddyzm był przede wszystkim religią skoncentrowaną na stanie duchownym i to właśnie jego dotyczyły szczegółowe regulacje. Dla laikatu właściwie jedynym obowiązkiem było podtrzymywanie przy życiu mnichów, co skutkowało nagromadzeniem zasługi w formie dobrego karmana i korzystnym odrodzeniem. Takie rozłożenie akcentu było usprawiedliwione trudnościami, jakie przysparzało posiadanie rodziny i spełnianie obowiązku zarobkowania na jej utrzymanie. Trudności te były dwojakiego rodzaju: $\mathrm{z}$ jednej strony brak czasu i energii na praktykę religijną, a $\mathrm{z}$ drugiej strony trudność $\mathrm{w}$ osiągnięciu równowagi emocjonalnej w sytuacji ciągłego zaangażowania w relacje oraz światowe sprawy.

Dalszy fragment omawianego tekstu zawiera zalecenia dotyczące postawy psychologicznej: „Nie myśl o dobru i złu. Nie zajmuj się prawdą ani fałszem. Powściągnij działania umysłu, intelektu i świadomości. Zatrzymaj kalkulacje myśli, idei i zmysłów" ${ }^{17}$.

Rzeczywistość medytacji w pozycji siedzącej przekracza wszystkie przeciwieństwa. Eliminuje wszystkie punkty odniesienia, w stosunku do których możliwy jest sąd wartościujący, i w ten sposób niemożliwa staje się ocena praktyki jako lepszej lub gorszej. Medytacja nie może opierać się na rozumieniu intelektualnym - nieodmiennie zakładającym intencjonalne działanie zmierzające $\mathrm{w}$ jakimś kierunku - ponieważ $\mathrm{w}$ istocie nie ma $\mathrm{w}$ niej niczego do zrozumienia na poziomie dyskursywnej świadomości. Także dążenie do stania się buddą i ustanawianie tego jako celu praktyki jest tworzeniem kolejnego co prawda ostatecznego, ale jednak - punktu odniesienia. Ten subtelny i trudno dostrzegalny błąd, przed którym przestrzega Dōgen w kolejnym niezwykle

\footnotetext{
15 Tamże.

16 Tamże.

17 Tamże.
} 
istotnym wskazaniu, nieobecnym we wcześniejszej wersji Tenpuku: „Nie staraj się stworzyć Buddy, nie bądź przywiązany do siedzenia w bezruchu"18.

Sama intencja zostania buddą za pomocą medytacji jest rodzajem uromantycznionej wizji stanu buddy. Element linearnego rozwoju adepta polega właśnie na usunięciu tych romantycznych wizji, zasłaniających zupełnie realne konsekwencje praktyki tylko siedzenia (jap. shikan taza 只管打坐) oraz każdej innej aktywności - tradycyjnie podporządkowanej leżeniu, staniu oraz chodzeniu. Bycie przywiązanym do siedzenia w bezruchu może odnosić się do dwóch kwestii. Pierwsza z nich dotyczy militarnego stylu siedzenia. Polegał on na wymuszaniu napięcia mięśniowego w trakcie przyjmowania tej pozycji, co miało dawać złudne poczucie pewności prawidłowej praktyki. Już samo to wskazuje na intencjonalne działanie, przed którym cały czas przestrzegał Dōgen. Drugi sens tej wypowiedzi odnosi się do przeświadczenia, jakoby praktyka ograniczała się wyłącznie do siedzenia, a wszystko, co wydarza się poza nią, jest traktowane jako trwonienie czasu. Pokutuje tutaj nieprawdziwe rozróżnienie na sacrum i profanum, obce nurtowi mahajany.

Kolejne fragmenty tekstu dotyczą już ściśle technicznych aspektów praktyki, mających swoje korzenie w tradycji. Dōgen poucza, między innymi, o potrzebie maty, poduszki oraz instruuje adepta o właściwym ułożeniu nóg, w zgodzie z przykładem starożytnych mistrzów medytacji. Oto dalsze napomnienia:

W miejscu, w którym zwykle siadasz, rozłóż grubą matę i na jej środku połóż poduszkę. Siadaj albo w pełnym skrzyżowaniu nóg [pełny lotos], albo połowicznym skrzyżowaniu nóg [półlotos]. Jeżeli chodzi o pełną pozycję, najpierw połóż prawą stopę na lewym udzie, a następnie lewą stopę na prawym udzie. Jeżeli chodzi o połowiczną pozycję, po prostu połóż lewą stopę na prawym udzie ${ }^{19}$.

Pozycja pełnego lub połowicznego lotosu w siadzie na poduszce powoduje, że ciało zdobywa trzy punkty oparcia, pośladki oraz spoczywające niżej na macie kolana. Biodra naturalnie wysuwają się do przodu, a kręgosłup prostuje się bez użycia wysiłku. Od właściwego ułożenia nóg oraz wysokości poduszki zależy jakość całej sesji medytacyjnej, która nie powinna być - jak wspomniano wyżej - ascetyczną walką z bólem. Spośród wszystkich możliwych pozycji medytacji, pozycja lotosu jawi się jako wyjątkowo trudna dla mieszkańców Zachodu, jednak według wielowiekowej tradycji została wypracowana i sprawdzona jako najbardziej odpowiednia dla długich sesji medytacyjnych. Jeśli chodzi o skrajności w tym względzie, to z jednej strony mamy

\footnotetext{
18 Tamże.

19 Tamże, s. 178.
} 
przykład mnichów dżinijskich, którzy medytują na stojąco, z drugiej frywolność, mówiącą o tym, że każda pozycja jest właściwa. W pierwszym przypadku konfrontujemy się z niepotrzebnym napięciem, $\mathrm{z}$ drugiej strony $\mathrm{z}$ ospałością. Oba te ekstrema nie są pożądane, a środkową drogą między nimi jest właśnie pozycja pełnego lotosu. W kolejnym akapicie Dōgen kontynuuje opis pozycji ciała: „Poluzuj swoją szatę oraz pas i właściwie je uporządkuj. Następnie umieść swoją prawą dłoń na lewej stopie, a lewą dłoń na prawej dłoni. Złącz swoje kciuki. Później wyprostuj swoje ciało i siedź w ten sposób. Nie przechylaj się ani na lewo, ani na prawo, ani do przodu, ani do tyłu"20.

Pozycja rąk ma w buddyzmie duże symboliczne znaczenie. Ta opisana przez Dōgena to kosmiczna mudra (jap. hokkai join 法界定印), która kształtem przypomina owal, czyli najpopularniejszy symbol graficzny, z którym kojarzony jest buddyzm zen. Podobnie, symbolem, z którym najczęściej kojarzony jest buddyzm tybetański, jest owalna mandala - reprezentuje ona pełnię i doskonałość. Prawidłowa postawa jest symetryczna i prostopadła w stosunku do płaskiego podłoża, co w połączeniu z nienagannym ułożeniem szat, ma również wymiar estetyczny, który u obserwatora wywołuje odczucia elegancji i wzniosłości. Nie bez powodu figury historycznego Buddy przedstawiają go najczęściej właśnie w pozycji lotosu. Oto kontynuacja drobiazgowego opisu pozycji ciała: „Twoje uszy powinny być równoległe z ramionami, a nos w prostej linii z pępkiem. Przyciśnij język do przedniej części podniebienia i zamknij usta oraz zęby. Oczy powinny być zawsze otwarte. Oddychaj spokojnie przez nos"21.

Każdy czytelnik Dōgena może łatwo zauważyć, jak w wybranych wypowiedziach bardzo dba on o szczegóły, zwłaszcza kiedy nie jawią się one jako najistotniejsze aspekty praktyki. Niestety ta tendencja nie jest ciągła - co prawdopodobnie jest zamierzone - i czasami skazani jesteśmy na domysły, czego przykładem będą następne wersety.

\section{Sedno praktyki I}

Od tego miejsca kończą się uwagi techniczne, a rozpoczyna coś, co można określić jako kamień węgielny Fukan zazengi, mianowicie fragment dotyczący samego sedna praktyki. Wyjątkowo dokonam tutaj analizy obu wersji tekstu, z uwagi na zasadniczą różnicę, jaka w nich występuje. Oto fragment ze starszej wersji Tenpuku: „Kiedy uregulowałeś swoją postawę, weź jeden głęboki wdech i zrób pełny wydech. Pokołysaj się na lewo i prawo.

\footnotetext{
20 Tamże, s. 179.

21 Tamże, s. 180.
} 
Kiedykolwiek myśl się pojawi, bądź jej świadom. W momencie, w którym stajesz się jej świadom, ona znika"22.

Po zapoznaniu się z powyższym może pojawić się refleksja: Do kogo tak naprawdę zwraca się Dōgen w tym zdaniu? Jakiego rodzaju podmiotem jest ten, który uświadamia sobie pojawiającą się myśl? W kontekście buddyjskiej nauki o nieistnieniu trwałego substancjalnego Ja to coś, co uświadamia sobie myśl, nie jest jakimś konkretnym podmiotem, ale tylko inną myślą. Aby ten proces myślowy mógł być kontynuowany, musi zachodzić złudzenie o istnieniu niezależnego - a więc istniejącego realnie - od myśli podmiotu. Aby ta iluzja mogła się utrzymać, musi mieć zapewnione odpowiednie warunki ciągłego napływu bodźców. Jeżeli te bodźce zostaną wyeliminowane, a jedynym zajęciem pozostanie tylko siedzenie, to $\mathrm{w}$ tym stanie podmiot wraca do punktu, w którym żaden proces myślowy nie może się utrzymać przez dłuższy czas. Mówiąc inaczej, to w prostym siedzeniu pozbawionym celu proces myślowy musi dojść do punktu, w którym niemożliwe jest jego dalsze kontynuowanie. W tym punkcie jako ostatnia pojawia się myśl uświadamiająca myślenie, która niszczy cały proces. Determinacja, która nie pozwala na kompromisy, doprowadza do momentu, w którym podmiot urzeczywistnia swoją naturę $^{23}$, że on sam nie jest niczym innym jak tylko kolejną myślą spoglądającą na siebie.

Potwierdzenie tego znajdujemy w dalszym fragmencie: „Jeśli przez długi czas zapomnisz o wszystkich rzeczach [przedmiotach], naturalnie staniesz się całością. Oto sedno sztuki siedzącej medytacji. Siedząca medytacja to brama dharmy wielkiego spokoju i radości" ${ }^{24}$. Nie ma tutaj mowy o formie intencjonalnego działania polegającego na staraniach o zapominaniu o wszystkich rzeczach, ponieważ wszelka forma intencji petryfikuje podział na podmiot i przedmiot. Dōgen w tym zdaniu stwierdza, że aby zapomnieć o wszystkich rzeczach, niezbędne jest zapomnienie o samym sobie - jest to proces symultaniczny, ponieważ podmiot i przedmiot definiują się nawzajem. Bez względu na to, czy mowa o zapominaniu o podmiocie lub przedmiocie, jedynym sposobem jest studiowanie samego siebie, czyli, według Dōgena, praktyka buddyjskiej medytacji. Dobitnie pisze o tym sam autor Fukan zazengi w pierwszym rozdziale Shōbōgenzō: „Uczenie się i poznawanie Drogi Buddy jest poznawaniem samego siebie [«ja»]. Uczenie i poznawanie samego siebie jest Zapomnieniem o samym sobie"25.

Czyli zapomnieniem o wszystkich rzeczach i staniem się jedną całością $\mathrm{w}$ absolutnej koincydencji $\mathrm{z}$ całym wszechświatem, jak mówi o tym

\footnotetext{
22 Tamże, s. 181.

${ }^{23}$ Ściślej, brak jakiejkolwiek natury. To typowy paradoksalny styl wypowiedzi w zenie.

${ }^{24}$ C. Bielefeldt, Dōgen's Manuals..., s. 181.

${ }^{25}$ Dōgen, Oko i skarbiec prawdziwego prawa, s. 56.
} 
wcześniejszy fragment ery Tenpuku. Wszystko to są procesy wydarzające się spontanicznie, zaś jedynym zadaniem spoczywającym na adepcie to - mówiąc w skrócie - zacząć i nie kończyć. Prawdziwym sednem praktyki jest więc determinacja.

\section{Sedno praktyki II}

Pozostaje w sferze domysłów, dlaczego Dōgen zmienił ten fragment w tekście Koroku na koan z mistrzem chanu Yaoshanem Hongdao. Z całą pewnością jest to najbardziej zagadkowa modyfikacja, zwłaszcza że dotycząca punktu, w którym autor wyjawia esencję praktyki. Być może miało to nadać pismu bardziej oryginalny charakter, ale bardziej prawdopodobnym powodem mógł być lęk przed uznaniem wcześniejszego opisu jako zachęty do wysiłku woli i intelektu celem uspokojenia umysłu. Słuszność takiego stanowiska uprawdopodabnia inna zmiana w tekście, wskazanie nieobecne w wersji wcześniejszej, w którym Dōgen zaleca, aby nie starać się zostać buddą za pomocą praktyki. Dodatkowo przemawia za tym pojawiające się dalej napomnienie, aby nie sądzić, że medytacja w pozycji siedzącej, której naucza, jest podobna do innych praktyk medytacyjnych. Warto nadmienić, że w zwoju dwunastym Shōbōgenzō zatytułowanym Napomnienia dotyczace siedzacej medytacji ${ }^{26}$, Dōgen dokonuje egzegezy wskazanego koanu z typową dla siebie finezją. Z uwagi na rozmiary artykułu skupiam się jedynie na własnej interpretacji tego fragmentu z pominięciem komentarza do egzegezy Dōgena. Przyjrzyjmy się zatem zmienionej wersji, zdanie po zdaniu: „Siedząc nieporuszonym, myśl o niemyśleniu"27.

Początkujący adept zawsze będzie próbował za pomocą umysłu uspokoić umysł lub za pomocą myśli powściągnąć myśl. Jest to złudzenie kontroli, wynikające $\mathrm{z}$ wiary $\mathrm{w}$ odseparowany od myśli, realnie istniejący podmiot. Przypomina to próbę lewitacji lub choćby oderwania się od ziemi poprzez uchwycenie własną ręką własnych włosów i ciągnięcia ich w górę ${ }^{28}$. W jaki sposób wybrnąć z tego błędnego koła? Dōgen pisze dalej: „Czym jest myślenie o niemyśleniu? Nie-myślenie [to coś innego niż myślenie]"29.

Nie ma żadnego sposobu. Myślenie o niemyśleniu to spontaniczny proces tożsamy z fizycznym aspektem tylko siedzenia, nie ma między nimi żadnej różnicy. Samo więc pytanie jest bezsensowne, tak samo jak bezsensowna jest odpowiedź na nie. Bez względu na to, czy przetłumaczylibyśmy to

\footnotetext{
26 Tamże, s. 215-222.

27 C. Bielefeldt, Dōgen's Manuals..., s. 181.

${ }^{28}$ Nawiązuję oczywiście do osobliwej przygody Barona Muenchhausena.

${ }^{29}$ C. Bielefeldt, Dōgen's Manuals..., s. 181.
} 
jako np. niemyślenie, pozamyślenie, ponadmyślenie albo nawet myślenie, to i tak pozostalibyśmy w tej samej zagadkowej sytuacji braku odpowiedzi. Najdobitniej ujmuje tę trudność zachodni myśliciel Ludwig Wittgenstein w tezie 6.5 swojego słynnego traktatu: „Do odpowiedzi, której nie można wyrazić, nie można też wyrazić pytania. Wielka zagadka nie istnieje. Jeżeli jakieś pytanie da się w ogóle postawić, to można też na nie odpowiedzieć" 30 .

Nie tylko całe Fukan zazengi, ale również wszystkie inne pisma Dōgena zawierają w sobie element pewnej ironii. Całe Shōbōgenzō jest właściwie zbiorem żartobliwych pytań, co bynajmniej nie jest interpretacją lekceważącą, a wręcz przeciwnie, z czym zapewne zgodziłby się Wittgenstein. Oto przypisywana mu, dotycząca tego wypowiedź: „Poważna i dobra praca filozoficzna mogłaby być wypełniona w całości żartami (jednocześnie nie będąc banalną)" "31.

Ślepą plamką, która utrudnia spostrzeżenie tego faktu, jest to, że osobą, z której żartuje Dōgen, jest sam czytelnik. Docenienie tego rodzaju humoru wymaga więc pewnego dystansu. Nie może to bynajmniej być usprawiedliwieniem rezygnacji z praktyki, wręcz odwrotnie jest dopiero jej początkiem. Dlatego Dōgen przypomina pisarza kryminałów, który na pierwszych stronach książki wyjawia zakończenie powieści, a następnie prowadzi czytelnika przez całą historię, nieprzerwanie utrzymując napięcie. Przypominając metaforę z początku tekstu, można zasadnie stwierdzić, że cała historia sprowadza się do pokonania cienkiego jak włos zwątpienia, które wystarcza, aby oddzielić praktykę od oświecenia.

Japoński myśliciel konkluduje następującymi słowami: „Oto sedno sztuki medytacji w pozycji siedzącej"32.

Prawidłowa praktyka medytacyjna rozpoczyna się dopiero po okresie przejściowym, w którym intencjonalne działanie pozornego podmiotu się wyczerpuje. Ten proces ma własną dynamikę, dlatego autentyczna praktyka nie jest możliwa od samego początku. Następuje ona dopiero po dość długim okresie powolnego rozczarowywania własnymi możliwościami. Na Drodze buddów i patriarchów nie ma skrótów. Dlatego sednem praktyki zen jest determinacja, a nie jakaś forma techniki - trzeba pukać w bramę, dopóki się nie otworzy, a potem pukać dalej - o czym Dōgen wspomina w następnym zdaniu: „Medytacja w pozycji siedzącej [zazen] nie jest praktyką dhyany [shuzen], to po prostu brama dharmy wielkiego spokoju i radości" ${ }^{33}$.

Medytacja w pozycji siedzącej nie może być postrzegana jedynie jako linearny proces rozpoczynający się od ignorancji i zwieńczony spektakularnym

\footnotetext{
${ }^{30}$ L. Wittgenstein, Traktat logiczno-filozoficzny, thum. B. Wolniewicz, Warszawa 2000, s. 82.

${ }^{31}$ N. Malcolm, Ludwig Wittgenstein: A Memoir, Oxford 2001, s. 27-28.

${ }^{32}$ C. Bielefeldt, Dōgen's Manuals..., s. 181.

33 Tamże.
} 
oświeceniem, jak rozumiana była praktyka dhyany lub shuzen przekazywana przez pielgrzymów przed Dōgenem. Ta wizja musi zostać uzupełniona o prawidłowe rozumienie medytacji wolnej od kompulsji osiągania, a więc takiej, w której ostateczne oświecenie jest zupełnie zwykłym doświadczeniem jedności praktyki i oświecenia, o czym mówi kolejne zdanie: „To praktyka i potwierdzenie [oświecenia] ostatecznego przebudzenia" 34 , które to ostateczne oświecenie jest stanem wolnym od wszelkich wątpliwości. Żadne pytanie nie może się utrzymać w świadomości oświeconego człowieka. Jeżeli bowiem nie ma na nie odpowiedzi, to pytania też - tak naprawdę - nie ma. Oto kolejne zdanie: „To zrealizowany koan, kosze i klatki nie mogą tego dosięgnąć" 35 .

Urzeczywistnienie koanu jest tożsame $\mathrm{z}$ odrzuceniem koanu. Pytanie, na które - ponad wszelką wątpliwość - nie ma odpowiedzi, musi zniknąć. Introspekcja koanu jest integralną częścią medytacji zen - w mojej ocenie różnica jest formalna - nie mamy do czynienia $\mathrm{z}$ dwiema odrębnymi formami praktyki, jednak ze względu na objętość tej pracy nie mogę w pełni rozwinąć tej problematyki.

Rezultatem praktyki jest stan pełnej integracji wewnętrznej i zewnętrznej. Dōgen pisze o tym w ten sposób: ,Jeśli uchwycisz punkt tej praktyki, będziesz jak smok nurkujący w wodzie albo jak tygrys skaczący po górach. Musisz zrozumieć, że w momencie, kiedy właściwa postawa [pogląd] jest obecny, senność i rozproszenie, od samego początku, są odsunięte na bok"36.

W mitologii japońskiej naturalnym środowiskiem dla smoka jest woda, zaś dla tygrysa góry i lasy. Tak samo dla autentycznego adepta, który uchwycił sedno praktyki, każde miejsce jest właściwym miejscem i każdy dzień jest dobrym dniem ${ }^{37}$. Jeżeli ostateczny cel jest od zawsze osiągnięty, to wszystkie neurotyczne wątpliwości zostają odcięte od gruntu, z którego wyrastają.

\section{Końcowe napomnienia}

Rozważania dotyczące sedna praktyki Dōgen konkluduje krótkim zdaniem o właściwym kończeniu sesji medytacyjnej: „Kiedy podnosisz się z siedzenia, poruszaj się powoli i wstań spokojnie. Nie spiesz się"38.

Ta ostatnia techniczna uwaga kończy właściwą część instrukcji i rozpoczyna wspomnienia o dawnych mistrzach oraz ich metodach. Najpierw Dōgen

\footnotetext{
${ }^{34}$ Tamże.

35 Tamże.

36 Tamże, s. 182.

37 Powiedzenie Baizhanga (749-814), twórcy reguł monastycznych chanu.

${ }^{38}$ C. Bielefeldt, Dōgen's Manuals of Zen Meditation, s. 183.
} 
stwierdza: „Biorąc pod uwagę przeszłość, widzimy, że przekraczanie profanum i przekraczanie sacrum, porzucanie tego ciała podczas siedzenia oraz odrzucania tego ciała podczas stania jest zupełnie podporządkowane tej mocy"39.

Mistrzowie dawnych epok przekraczali wszystkie dualizmy, odrzucając przywiązania i w pełni oddając się praktyce. Bez względu na to, czym się zajmowali, zawsze działali w pełnym skupieniu, bez zwracania uwagi na własne zdrowie i życie (ponieważ wszystko traktowali jako części tej samej praktyki). Mimo że praktykowali to samo, to jednak różnili się między sobą. Zwraca na to uwagę kolejny fragment:

Z pewnością więc, aby uchwycić zmianę okazji poprzez palec, drążek, igłę lub młotek i aby przedstawić weryfikację w zgodzie z miotełką, pięścią, kijem albo krzyknięciem. Nie jest to coś, co można zrozumieć za pomocą rozróżniającego myślenia, jeszcze mniej za pomocą praktyki i potwierdzenia nadnaturalnych zdolności ${ }^{40}$.

Zrozumienie zachowania starożytnych mistrzów nie jest zadaniem dla intelektu. Bez względu na to, jak bardzo przeświadczeni jesteśmy o autorytecie dawnych mistrzów, nie zrozumiemy tego jedynie poprzez studiowanie ich wyjątkowych metod nauczania. Nawet będąc świadkiem cudownych zdarzeń, nie mamy pewności zrozumienia ich znaczenia. Niezbędne jest poznanie korzenia, z którego wyrasta ich zrozumienie. Ten korzeń jest czymś, co wymyka się racjonalizacji, o czym Dōgen pisze dalej w ten sposób: „Muszą oni [dawni mistrzowie] reprezentować postępowanie poza dźwiękiem i formą. Jak mogliby nie zapewnić właściwego standardu [zachowania] przed wiedzą i zrozumieniem?"41.

Praktyka medytacji w pozycji siedzącej, której z zapałem oddawali się dawni mistrzowie, nie czyniła z nich mistrzów. Według Dōgena musieli oni być mistrzami jeszcze przed rozpoczęciem praktyki, w przeciwnym razie nigdy nie rozpoznaliby medytacji w pozycji siedzącej jako jedynej drogi buddów i patriarchów. Mimo że praktyka pozostaje taka sama, to ekspresja oświeconej natury jest zależna od specyfiki osobowości i środowiska. Dawni mistrzowie znani byli ze stosowania uderzeń, krzyków lub paradoksalnych wypowiedzi, nie należy jednak skupiać się na nich i silić na ich interpretację, grozi to bowiem utratą $\mathrm{z}$ horyzontu wspólnego mianownika tego rodzaju ekscentryzmów. Osobliwe przykłady z przeszłości nie powinny być onieśmielające, o czym Dōgen jasno stwierdza:

Dlatego nie ma to znaczenia, czy ktoś jest bardzo inteligentny albo bardzo głupi. Nie ma różnicy pomiędzy tymi wybitnymi lub niskimi zdolnościami.

\footnotetext{
39 Tamże, s. 184.

40 Tamże.

${ }^{41}$ Tamże.
} 
Skoncentrowany wysiłek jest sam w sobie osiągnięciem Drogi. Praktyka i weryfikacja [oświecenie] są z natury niesplamione. Postęp w stronę oświecenia to kwestia codziennych spraw ${ }^{42}$.

Inteligencja, a w jeszcze mniejszym stopniu wiedza dyskursywna, nie mają znaczenia, jeżeli adept oddaje się praktyce z pełnym zapałem, oddalając od siebie wszystko inne. Według autora Fukan zazengi, praktyka kogoś takiego nie różni się od praktyki samego historycznego Buddy. Medytacja w pozycji siedzącej jest czysta, ponieważ bez względu na to, czy praktykuje ją geniusz lub ignorant, święty albo pospolity grzesznik, to w samym fakcie siedzenia następuje coincidentia oppositorum, w której najwyższe sacrum nie różni się od codziennych aktywności świata profanum. Dalej padają słowa o przykładzie buddów i patriarchów:

W naszym świecie oraz innych miejscach, od Zachodniego Nieba i Wschodniej Ziemi, wszyscy w takim samym stopniu podtrzymują pieczęć Buddy, ciesząc się własnym stylem nauczania. Poświęcają się wyłącznie siedzeniu, są uwięzieni przez wyprostowaną postawę. Mimo że mówią o dziesięciu tysiącach rozróżnień i tysiącu różnic, to i tak jedyne, co robią, to praktykują zen i podążają drogą ${ }^{43}$.

Nie tylko w Fukan zazengi, ale we wszystkich swych pismach Dōgen przekonuje, że jedyną drogą prowadzącą do oświecenia jest nieporuszone siedzenie, pozbawione nawet najbardziej chwalebnej motywacji. Bez względu na wszystkie nauki oraz wachlarz praktyk nigdy nie powinniśmy stracić z oczu tego, co stanowi podstawę buddyzmu. Dlatego następny fragment napomina o niezbędnym pośpiechu: „Dlaczego opuszczać poduszkę we własnym domu i wędrować po piaszczystych regionach innego kraju? Jeśli uczynisz jeden fałszywy krok, ominie cię to, co jest dokładnie przed tobą. Skoro już masz funkcjonalną esencję ludzkiego ciała, nie spędzaj dni na próżno"44.

Tutaj japoński mistrz zniechęca czytelnika do pójścia jego śladami. Skoro bowiem on sam odnalazł prawdę i przekazuje ją w formie Fukan zazengi, to nie ma konieczności, aby inni marnowali czas na kolejne religijne pielgrzymki. $\mathrm{W}$ jeszcze większym stopniu odnosi się to do poszukiwania wrażeń w świecie doczesnym: „Kiedy troszczysz się o funkcjonalną esencję drogi Buddy, czy jest możliwe dalsze cieszenie się iskrą z krzemienia?"45.

Dla dorosłego człowieka nie jest możliwy powrót do stanu dzieciństwa i cieszenia się prostymi zabawami. Gdyby tak się stało, mówilibyśmy

\footnotetext{
42 Tamże, s. 185.

43 Tamże.

44 Tamże, s. 186.

45 Tamże.
} 
o patologicznym mechanizmie obronnym nazwanym regresją, który jest reakcją ucieczki przed wyzwaniami dojrzałego życia. Dokładnie w taki sam sposób człowiek, który rozpoznał prawdę w dharmie, nie może dłużej absolutyzować sukcesów i porażek życia doczesnego. „Zaiste forma i substancja są jak kropla rosy na źdźble trawy, a dobre powodzenie niczym światło błyskawicy, w jednej chwili stają się puste, w jednym momencie są utracone" 46 .

Dōgen napomina o tym, że czasu pozostało bardzo niewiele, dlatego adepci, którzy poważnie traktują buddyzm, nie powinni zajmować się poprawą swoich warunków życiowych i zmianą okoliczności. Każdy wysiłek skierowany w stronę inną niż medytacja w pozycji siedzącej jest wysiłkiem skierowanym w złym kierunku. Dlatego Dōgen przypomina, że ostateczny cel życia nie może być utylitarny - to nie zdrowie i długie życie jest najważniejsze, tylko wierność prawdzie nawet za cenę życia.

Dōgen zdecydowanie zachęca do postawienia wszystkiego na jedną kartę, sugerując, że wszystkie racjonalne obawy są tylko objawem iluzji, a więc uznawania jakiegoś elementu rzeczywistości za nieprzemijający. Japoński mistrz zaleca medytację w pozycji siedzącej jako najlepszy lek na wszystkie troski, tak światowe, jak i ostateczne. W ostatnim akapicie Dōgen tymi słowami podsumowuje treść Fukan zazengi:

Wybitni uczniowie dharmy, od dawna przyzwyczajeni do szukania słonia, módlcie się, abyście nie zwątpili, kiedy objawi wam się prawdziwy smok. Podążajcie drogą, która wskazuje bezpośrednio na rzeczywistość. Szanujcie człowieka, który zrozumiał naukę i jest zupełnie wolny w działaniu. W zgodzie $\mathrm{z}$ oświeceniem wszystkich Buddów. Dziedzicząc samadhi wszystkich Patriarchów. Jeśli w ten sposób będziesz czynił przez długi czas, to niedługo staniesz się właśnie taki. Twój skarbiec otworzy się sam z siebie i będziesz mógł go używać tak, jak zechcesz ${ }^{47}$.

Autor obiecuje, że wiernie naśladując zachowanie Buddy, każdy, prędzej czy później, musi w pełni rozwinąć swój potencjał. Nawet jeśli początkowej praktyce brakuje autentyczności, to ostatecznie, pod wpływem niezachwianej dyscypliny, praktykując na wzór buddów i patriarchów, adept spontanicznie stanie się jednym z nich. Przebywanie w odpowiednim towarzystwie determinuje postawę, możemy wobec tego zaryzykować stwierdzenie, że praktyka medytacji w pozycji siedzącej, jest bliskością z buddami i patriarchami linii przekazu, do której pełne zaufanie jest warunkiem koniecznym i wystarczającym.

\footnotetext{
46 Tamże.

47 Tamże, s. 187.
} 


\title{
FUKAN ZAZENGI BY DōGEN AS A TEXT REVEALING THE ESSENTIAL FEATURES OF BUDDHIST PRACTICE
}

\begin{abstract}
The aim of this article is the presentation and relatively detailed analysis of the text written by the medieval monk Dogen entitled Fukan zazengi. This is one of the most important religious scriptures in the history of Japanese Buddhism and Buddhism in general, constituting the basic instructional manual within the wide Mahayana current. In the article I present the author's view, which boils down to emphasizing the importance of independent meditation practice based on examples of former masters. At the same time, I emphasize the final mystery of the actual practice itself and Dogen's advice to reject the understanding of religious practice in terms of profit and loss.

The paper also touches the problem occurring within two versions of the discussed meditation instruction. The differences in the two texts are twofold, on the one hand, more or less significant corrections throughout the whole text and on the other hand one fundamental change that determines the core of religious practice, which is, after all, a sine qua non of Buddhism. As I will try to prove, this change, contrary to appearances, is not as revolutionary as it might seem and both versions reveal the same secret of sitting meditation.
\end{abstract}

Keywords: Dogen, Fukan Zazengi, Shobogenzo, sitting meditation, religious practice, former masters, Buddhism, Mahayana, Zen, Wittgenstein

Słowa kluczowe: Dogen, Fukan zazengi, Shobogenzo, medytacją siedząc, praktyka religijna, dawni mistrzowie, buddyzm, mahajana, zen, Wittgenstein

\section{BIBLIOGRAFIA}

Bielefeldt C., Dōgen's Manuals of Zen Meditation, Berkeley 1988.

Dōgen, Oko i skarbiec prawdziwego prawa, tłum. M. Kanert, Kraków 2005.

Krishnamurti J., Total Freedom, San Francisco 1996.

Malcolm N., Ludwig Wittgenstein: A Memoir, Oxford 2001.

Wittgenstein L., Traktat logiczno-filozoficzny, thum. B. Wolniewicz, Warszawa 2007. 